Article

\title{
A Resident Fish Guild as a Higher Trophic Level Indicator of Oyster Reef Restoration Success
}

\author{
Dakota M. Lewis ${ }^{1,2, *}$, Katie E. Durham ${ }^{1}$, Linda J. Walters ${ }^{1}$ and Geoffrey S. Cook ${ }^{1}$ \\ 1 Department of Biology, University of Central Florida, Orlando, FL 32816, USA; \\ katieed@knights.ucf.edu (K.E.D.); linda.walters@ucf.edu (L.J.W.); geoffrey.cook@ucf.edu (G.S.C.) \\ 2 School of Natural Resources and Environment, University of Florida, Gainesville, FL 32611, USA \\ * Correspondence: dakotalewis@ufl.edu
}

Citation: Lewis, D.M.; Durham, K.E.; Walters, L.J.; Cook, G.S. A Resident Fish Guild as a Higher Trophic Level Indicator of Oyster Reef Restoration Success. Sustainability 2021, 13, 13004. https://doi.org/10.3390/

su132313004

Academic Editor: Matteo Convertino

Received: 6 October 2021

Accepted: 19 November 2021

Published: 24 November 2021

Publisher's Note: MDPI stays neutral with regard to jurisdictional claims in published maps and institutional affiliations.

Copyright: (c) 2021 by the authors. Licensee MDPI, Basel, Switzerland. This article is an open access article distributed under the terms and conditions of the Creative Commons Attribution (CC BY) license (https:/ / creativecommons.org/licenses/by/ $4.0 /)$.

\begin{abstract}
Eastern oysters (Crassostrea virginica) are critical foundation species in estuarine waters, but due to a combination of natural and anthropogenic pressures, oyster abundance has declined. Restoring oyster reefs and monitoring restoration success often focuses on oyster metrics, but relatively infrequently, responses of higher trophic level species and the production of related ecosystem services are accounted for. To address this, we compare the response of a resident reef fish guild (gobies, blennies, toadfish) to standard metrics of oyster restoration success. Using lift nets and seines, natural and restored reefs were monitored over a two-year period within Mosquito Lagoon, Florida, USA. Standard metrics are indicative of restoration success; live oyster density and reef thickness increased in restored reefs after 12 and 24 months. Combined, live oyster density and reef thickness were the best predictors of annual resident reef fish abundance compared to water quality metrics. These results suggest that the benefits of restoring oyster reef habitat are conferred to broader components of the food web, with benefits accruing to reef resident fishes that are a key trophic linkage between lower trophic level foundation species and higher trophic level predators inhabiting coastal ecosystems.
\end{abstract}

Keywords: oysters; restoration; goby; blenny; toadfish; Indian River Lagoon

\section{Introduction}

Over the past century, anthropogenic activities have greatly impacted and degraded coastal systems, resulting in widespread habitat loss [1-3]. The pressures driving coastal habitat loss are myriad, often interconnected, and are both natural and anthropogenic in origin [4-6]. Due to these factors, some coastal systems and their foundation species are threatened, with many ecosystems greatly reduced from their historic distributions and abundances [7-10]. Therefore, as near-field and far-field pressures continue to increase sea level, sea surface temperatures, and alter regional weather patterns, it is becoming increasingly important to take more holistic approaches to the protection and conservation of coastal ecosystems [4,11-14].

Resource managers have previously addressed the loss of higher trophic level species by using top-down management strategies focusing on a single species, but many of these efforts had limited success [15]. In many fisheries, management approaches to increase abundance, such as stocking higher trophic level sport fishes, have been shown to only temporarily increase abundance and eventually produce negative cascading effects [16-18]. More recently, coastal managers have been transitioning towards more complete ecosystem-based management (EBM) strategies to reduce risk in coastal ecosystems [19-22]. Frequently, EBM uses bottom-up approaches to protect entire ecosystems with the goal of increasing sustainability [23]. Often, these approaches begin with protecting habitats, many of which are considered essential fish habitat (EFH). Essential fish habitat is any habitat utilized by a fish as foraging grounds, breeding grounds, or refugia and many policies have been implemented globally to help ensure their protection [24-27]. 
Essential fish habitat is often created by foundation species (a large or numerically abundant species that provides food and habitat), and frequently, these species are ecosystem engineers that modify habitats and physically alter the environment [28-31]. Due to their relatively high abundance, foundation species support a multitude of species that comprise lower levels of the food web. For example, oysters create biogenic habitat used by lower trophic level fishes and invertebrates [30-32].

Globally, oysters are crucial ecosystem engineers [24,33]. Within estuaries along the east coast of North and South America, eastern oysters (Crassostrea virginica) create complex 3 -dimensional structures used for forage and refugia by numerous organisms [34,35]. However, over the past century, eastern oysters have seen an $\sim 85 \%$ decrease in filtration capacity in US estuaries, a $64 \%$ decline in oyster extent, and an $88 \%$ decrease in oyster biomass due to factors such as overharvesting, degraded water quality, and physical disturbances such as boat wakes [36-42]. Due to their critical role, a loss of oyster reefs within an estuarine system can have effects throughout the broader food web [43-47]. To mitigate decreases in oyster abundance, there have been ongoing efforts to enhance and restore oyster reefs, often involving the physical placement of recruitment substrate, and, where needed, the introduction of additional larvae/spat/broodstock [33,48,49].

The benefits of oyster reef restoration are far-reaching and range from an increase in fish and shellfish abundance to the maintenance of biodiversity to the production of ecosystem services and sediment accretion along estuarine shorelines [38,50-53]. More specifically, oyster reef restoration has enhanced EFH in estuarine systems by improving water quality, increasing habitat available for foraging, and through the creation of complex habitats that can provide refugia from predators, increasing survivorship $[24,33,54-56]$. Historically, restoration success has been assessed by quantifying oyster abundance and oyster density; however, more recent studies have started to assess the benefits of habitat restoration accruing at higher trophic levels $[33,35,48,57,58]$. Higher trophic level predators, such as wading birds and sport fish, often use oyster reefs to forage for invertebrates and smaller fishes, but they tend to have relatively high rates of movement and continue to forage over large spatial scales, creating challenges when attempting to understand the role of reef restoration to these more mobile and transient species $[59,60]$. However, some taxa such as invertebrates and small demersal fishes (hereafter reef residents) are relatively sedentary and spend their entire life cycles on or near an individual oyster reef.

Many of these smaller demersal fishes are generalists in both environmental ranges and diet (Table 1). Reef residents generally occupy intermediate trophic levels within the broader reef food web, acting as predators of spat, copepods, amphipods, and polychaetes, but also serving as prey to higher trophic level predators [35,61]. These reef resident taxa are reliant on the 3-dimensional structure of oyster reefs, using interstitial spaces within the live oyster reef matrix as refugia from predators and for foraging and nesting habitat [35,53-55,62]. Many species of gobies, blennies, and toadfish are territorial, often showing high site fidelity, especially males during the breeding season [63]. Some blenny species have shown site fidelity across multiple breeding seasons, suggesting lifetime nesting site fidelity [63]. For example, in one of the most extensive mark-recapture studies on goby and blenny site fidelity, Harding et al. (2020) found that of the individuals recaptured, nearly all individuals (e.g., $94 \%$ of breeding males) were captured on the same oyster reefs where they were initially tagged. The findings of this study suggest the spatial scale of movement is less than $40 \mathrm{~m}$ for males [63]. This further indicates that many reef residents rely partially on larval dispersal for the movement of the species from site to site [64,65]. In Florida, this dispersal occurs for many of these species during the wet season (i.e., increased precipitation and temperature occur annually from May through October) (Table 1; [66,67]). The larval settlement of these fishes was found to occur downcurrent of reefs next to structured relief $[34,64,68,69]$. Similarly, vertical height and quality of interstitial spaces are important factors leading to the recruitment of oyster spat, potentially suggesting a correlation between reef residents and spat settlement [34]. Hence, reef residents that use oyster habitat for most of their life cycle may be valuable indicators 
for assessing restoration success or to assess if restored reefs are used similarly as live reefs by higher trophic level species [35]. The specific habitat features necessary to support these reef residents could have positive impacts on higher trophic level species that rely on them as prey. Thus, determining the oyster metrics that support reef residents (e.g., reef rugosity, oyster density) can be used to help guide and assess the goals of restoration projects [51,70].

Table 1. Reported environmental ranges or lower limits and northern hemisphere spawning season of species. Corresponding citations are listed in Appendix A, Table A2.

\begin{tabular}{cccccc}
\hline Species & Common Name & $\begin{array}{c}\text { Salinity } \\
(\mathbf{p p t})\end{array}$ & $\begin{array}{c}\text { Temperature } \\
\left({ }^{\circ} \mathbf{C}\right)\end{array}$ & $\begin{array}{c}\text { DO min. } \\
(\mathbf{m g} / \mathbf{L})\end{array}$ & Spawning Period \\
\hline $\begin{array}{c}\text { Bathygobius } \\
\begin{array}{c}\text { soporator } \\
\text { Chasmodes saburrae } \\
\text { Ctenogobius }\end{array}\end{array}$ & Frillfin Goby & $0-38.8$ & $17.0-36.0$ & 0.27 & July-August \\
$\begin{array}{c}\text { boleosoma } \\
\text { Gobiosoma bosc }\end{array}$ & Darter Goby & $0-34.0$ & $11.0-31.0$ & $\mathrm{NA}$ & May-October \\
$\begin{array}{c}\text { Gobiosoma robustum } \\
\text { Microgobius gulosus }\end{array}$ & Coded Goby & $0-45.0$ & $11.0-32.5$ & 0.86 & April-September \\
$\begin{array}{c}\text { Microgobius } \\
\text { Clowalassinus }\end{array}$ & Green Goby & $0-37.6$ & $10.0-33.5$ & $\mathrm{NA}$ & May-September \\
Opsanus tau & Oyster Toadfish & $1.0-36.6$ & $12.0-34.1$ & $\mathrm{NA}$ & March-November \\
\hline
\end{tabular}

To address this research need, here we examine the efficacy of using the local reef resident fish guild to provide a more holistic understanding of how reef restoration affects higher trophic level species [35,57]. More specifically, we explore knowledge gaps regarding how reef resident fish diversity and abundance responds to the restoration of oyster reefs within Mosquito Lagoon, Florida. These ecological data are compared with standard metrics of oyster habitat restoration to assess if habitat use, and the numerical response of reef resident fishes can be used as a higher trophic level indicator of oyster reef restoration success.

\section{Materials and Methods}

\subsection{Study Site and Restoration}

Mosquito Lagoon is the northernmost portion of the broader Indian River Lagoon (IRL), which spans approximately $250 \mathrm{~km}$ along Florida's central east coast (Figure 1A) [71]. The IRL contains extremely high biological diversity in part because it spans a dynamic biogeographic transition zone between temperate and subtropical climates [71-73]. Fish communities in Mosquito Lagoon have been well documented since the 1990s, with 87 taxa captured in recent studies [74,75]. Mosquito Lagoon is a shallow microtidal system with wind-driven currents $[37,76,77]$. Boat wakes are a major source of intertidal oyster reef degradation in Mosquito Lagoon [37,77]. Increased water motion dislodges oysters and oyster clusters from the sediment and deposits them above the mean water line, resulting in the loss of reefs and warranting the need for habitat restoration [37,77].

During the course of this study, three patch oyster reefs were restored (historic footprints restored where cluster loss was identified and reefs were dead) in June 2017, and an additional four patch reefs were restored in June of 2018 in a before/after control/impact design. These seven reefs were paired with four positive ("live" patch reef) controls and four negative ("dead" patch reef) controls; control reefs were not altered in the study (Figure 1B-D). Live reefs were characterized by a low vertical profile that ensured the reef was intertidal, with high rugosity and extensive live oyster cover [78]. Dead reefs were characterized by a relatively high vertical profile above mean water line, as oyster clusters would only accumulate on top of a live reef after being disturbed by boat wakes [79]. For additional information on reef slope, area, and elevation, please see Appendix A. Restored reefs were created by raking down dead shell piles to the intertidal water level, such that they were similar in vertical profile to adjacent live reefs [79]. Vexar-extruded polyethelene mesh mats (mesh openings $\sim 2.5 \mathrm{~cm} \times 2.5 \mathrm{~cm}$ with $2 \mathrm{~mm}$ wide mesh squares) commonly used in the aquaculture industry had clean oyster shells attached to the mats with cable 
ties to provide settlement substrate for larval spat (hereafter referred to as oyster mat) [77]. Subsequently, these mats were placed onto the raked areas and secured in place with concrete irrigation (donut) weights.

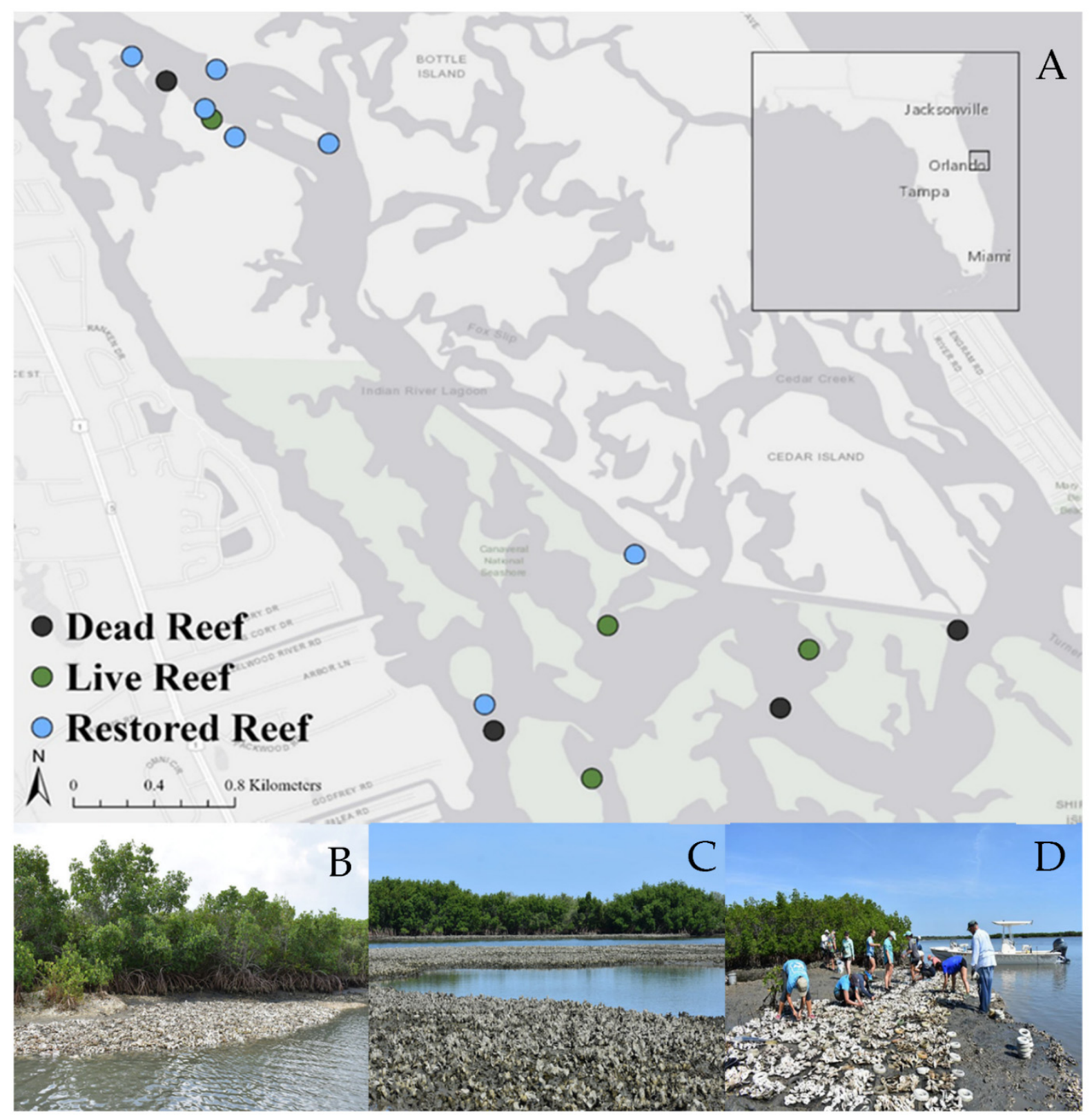

Figure 1. (A) Map of study sites within Mosquito Lagoon, Florida. Dead reefs are indicated by black dots, live by green dots, and restored by light blue dots; (B) Dead reef consisting of disarticulated shell; (C) Live reef at low tide; (D) Actively restoring reef by deployment of oyster mats. Photo credits: Linda Walters.

\subsection{Biotic and Abiotic Sampling}

Oyster reefs were monitored as in Baggett et al. (2015) and Chambers et al. (2018). Briefly, control and restored oyster reefs were monitored quarterly; mean live oyster count (oyster of all sizes were included in count) and mean reef thickness were estimated to better characterize the structural differences among treatment types. All live oysters were counted in five haphazardly placed $0.25 \mathrm{~m}^{2}$ quadrats and mean values estimated for each reef (hereafter referred to as oyster density). Mean reef thickness was estimated by placing $100.25 \mathrm{~m}^{2}$ quadrats per reef and measuring 10 haphazardly selected heights above 
sediment within each quadrat in $\mathrm{mm}$. Reef thickness is used to track fine-scale changes in vertical accretion of a reef until growth is capped by a local tidal range. Thickness also indicates higher structural complexity due to increased oyster growth $[68,80,81]$. The same sampling methodologies were used on all reef types.

The resident reef fish guild was sampled by placing six lift nets haphazardly along the long axis of an oyster reef (i.e., 3 nets just above MLW line and 3 nets just below MLW line to capture species using both the higher and lower portions of the reef) at fixed study sites. Lift nets were composed of $0.6 \mathrm{~m} \times 0.6 \mathrm{~m}$ PVC quadrats with $1.5 \mathrm{~mm} 16 \mathrm{~kg}$ delta netting with $0.3175 \mathrm{~cm}$ mesh to form a bag and deployed directly on each reef and allowed to soak (remain on the reef) for approximately one week. Lift nets placed on the reef contained one oyster mat which, upon sampling, would be removed and shaken into a bucket to capture all organisms. Lift nets were deployed two weeks pre-restoration and post-restoration at 1 week, 2 weeks, 4 weeks, 8 weeks, 12 weeks, and every 3 months thereafter. To capture more mobile species, a $21.3 \mathrm{~m}$ long seine with $2 \mathrm{~m} \times 2 \mathrm{~m}$ center bag with $0.3175 \mathrm{~cm}$ mesh was dragged along the length of each oyster reef $(\sim 30 \mathrm{~m})$, sampling the water column and benthos immediately adjacent to the study reef (i.e., inshore side of seine was pulled within one meter of the reef edge). Seining was conducted one week pre-restoration and post-restoration at 1 day, 1 week, 2 weeks, 4 weeks, 6 weeks, 8 weeks, 12 weeks, and every 3 months thereafter for 2 years. All fish captured were enumerated and a subset were stored in $95 \%$ ethanol and returned to the laboratory to verify species identification in accordance with University of Central Florida Animal Care and Use Committee Protocol (IACUC Permit \# 16-15W). Any individual collected from the genus Gobiosoma that was less than $20 \mathrm{~mm}$ in length could only be identified to genus accurately, and thus is referred to as Gobiosoma spp. in results. Associated environmental metrics were taken at the time of each fish sampling event. Temperature (C) and dissolved oxygen (DO; mg/L) were measured with a handheld YSI Pro DSS multiparameter probe at $50 \mathrm{~cm}$ water depth. Salinity (ppt) was quantified with a refractometer, and water clarity was estimated using a secchi disk (depth in m; as a proxy for turbidity). Secchi depth was taken prior to sample collection on reefs. All samples were collected around mid-tide to accommodate accessing sites via skiff.

\subsection{Statistical Analyses}

Mean abundance and species richness were quantified for each reef and sampling period. Catch per unit effort (CPUE) was calculated by gear type. A one-way analysis of variance (ANOVA) was used to test differences in abundance and richness among treatment types (live, dead, and restored) followed by a post hoc Tukey HSD test to identify differences (i.e., Tukey HSD $p<0.05$ ). To determine if there were differences among treatment types for each environmental metric, one-way ANOVAs were also performed for salinity, DO, temperature, secchi depth, mean live oyster count (number m-2), and reef thickness (height of reef above sediment in $\mathrm{mm}$ ). Normality of species abundance and richness were verified using Shapiro-Wilks tests, and homogeneity of variance was assessed using Levene's Test. Non-metric multidimensional scaling (NMDS) cluster analyses were performed to test for differences in species assemblages among treatment types (live, dead, restored) and seasons. Permutational multivariate analysis of variance (PERMANOVA) was used to quantify differences in species assemblages among treatment types [82,83]. Finally, the strongest abiotic and oyster metric predictors of fish abundance and richness were identified using generalized linear models (GLM). Models containing more than one predictor variable were assessed for collinearity using variance inflation factor [84]. Salinity and temperature quadratic models were included to assess the relationships among these species and these water quality variables as these species have documented salinity and temperature ranges (Table 1). Models were assessed using Akaike Information Criterion model selection (AIC), and $\mathrm{r}^{2}$ values were used to assess the ability of models to capture data variance $[83,85,86]$. High water levels continually submerge these oyster reefs late in the wet season and throughout the early dry season, thereby constraining the sampling of reefs. This resulted in significantly more sampling in the wet season than the dry season 
(i.e., until high water levels began to subside). Due to variation in the dry season species abundance and richness data, only wet season data were modeled.

\section{Results}

\subsection{Oyster Metrics}

There were no environmental differences among treatment types (all ANOVA $p$ values were $>0.1$ ). In the same region, seasonal differences are evident for all environmental metrics except Secchi depth (Table 2; [74]). Live reefs had higher mean live oyster density than dead reefs (Figure 2). Furthermore, mean reef thickness and oyster density at reefs restored in 2017 and 2018 increased consistently over time (Figure 2). After 12 months density of live oysters on restored reefs increased to $335.8 \pm 5.6$ oysters $\mathrm{m}-2$, and after 24 months density had increased to $430.0 \pm 11.3$ oysters $\mathrm{m}-2$. Similarly, reef thickness increased on restored reefs after $12(64.67 \pm 4.4 \mathrm{~mm})$ and 24 months $(71.5 \pm 2.9 \mathrm{~mm})$. Pooling data over time, live reefs had higher oyster density than both restored and dead reefs, and restored reefs had higher oyster density than dead reefs (ANOVA $F_{2,324}=99.97, p<2^{-16}$; all Tukey HSD post hoc adj $p$ values $<0.001$ ). A similar result was observed for mean reef thickness; live reefs had greater oyster reef thickness than dead reefs and restored reefs, while dead reefs had lower reef thickness than restored reefs (ANOVA $F_{2,328}=203.1, p<2^{-16}$; all Tukey HSD post hoc adj $p$ values $<0.001$ ). Restored reef metrics were variable; they resembled dead reefs and had relatively low counts pre-restoration but shifted to resemble live reefs with high oyster density in 12-14 months following restoration (Figure 2). However, as described above, restored reefs had oyster densities and reef thicknesses notably different than both live and dead reefs (even considering the temporal changes in thickness and abundance). Due to the growth at restored reefs resulting in changing oyster metrics over time, oyster density and reef thickness measurements were used as proxies for reef type in subsequent modeling.

Table 2. Means and standard deviations of environmental metrics in the study region annually and wet season. Adjusted $p$ values from Tukey HSD post hoc tests reported from comparison between wet and dry seasons [74].

\begin{tabular}{cccc}
\hline Environmental Metric & Annual Mean \pm SD & Wet Season Mean \pm SD & Seasonal Adj. $\boldsymbol{p}$ Value \\
\hline Salinity (ppt) & $33.91 \pm 3.98$ & $33.33 \pm 3.36$ & 0.003 \\
Temperature $\left({ }^{\circ} \mathbf{C}\right)$ & $27.12 \pm 4.76$ & $29.97 \pm 1.58$ & $<0.001$ \\
DO (mg/L) & $6.53 \pm 1.34$ & $5.92 \pm 1.35$ & $9 \times 10^{-5}$ \\
Secchi (m) & $0.72 \pm 0.24$ & $0.64 \pm 0.16$ & 0.11 \\
\hline
\end{tabular}

\subsection{Reef Resident Fish Guild}

A total of 1033 individuals representing 8 species of reef resident fishes were collected from 15 oyster reefs between May 2017 and June 2019 (Table 3). Live reefs yielded the most reef residents ( $n=667$ individuals). Dead reefs yielded 200 individuals, and restored reefs yielded 166 individuals. Species richness and total abundance increased as reef thickness and complexity increased (Figure 3). Species compositions were similar among treatment types with seven of the eight taxa occurring at each of the reef types; however, Microgobius thalassinus (Green Goby; $n=2)$ was only captured at dead reefs. Gobiosoma spp. $(n=321)$ was the most abundant taxa captured (Table 3). Gobiosoma spp., Gobiosoma robustum (Code Goby), and Microgobius gulosus (Clown Goby) were the three most abundant taxa at dead reefs. Live reefs and restored reefs had the same three most abundant species: Gobiosoma bosc (Naked Goby), Code Goby, and Ctenogobius boleosoma (Darter Goby). The Clown Goby and Frillfin Goby both had considerably greater counts during the wet season ( $t$-test $p$ values $<0.01$ ). 


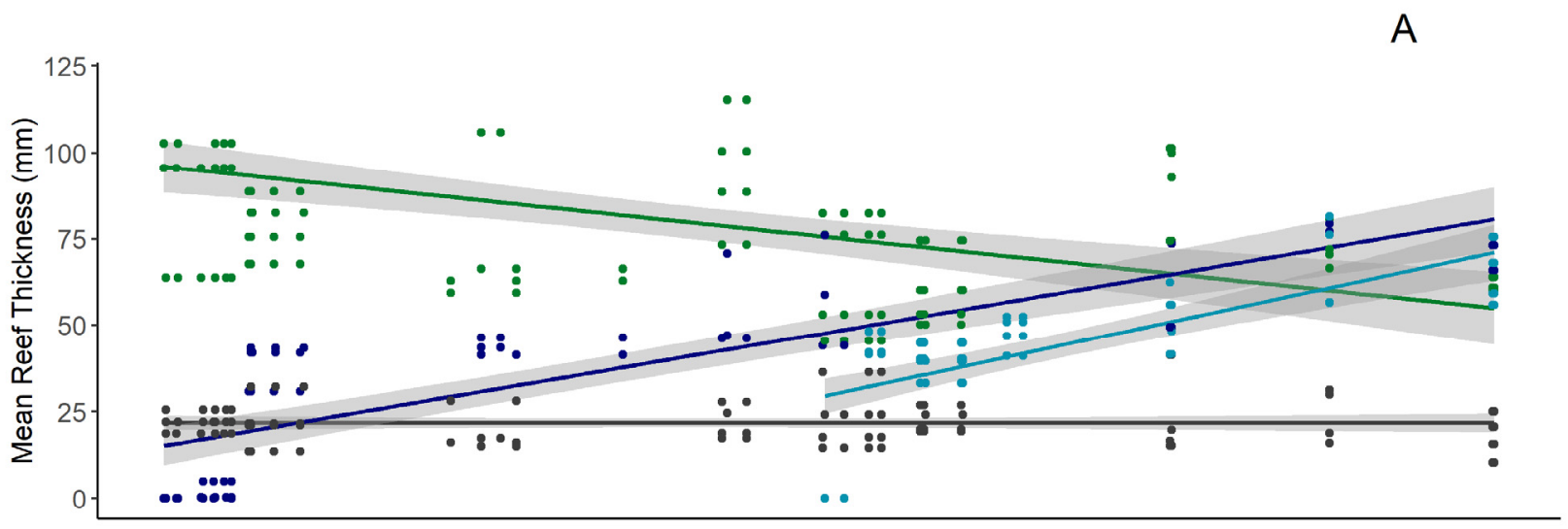

B

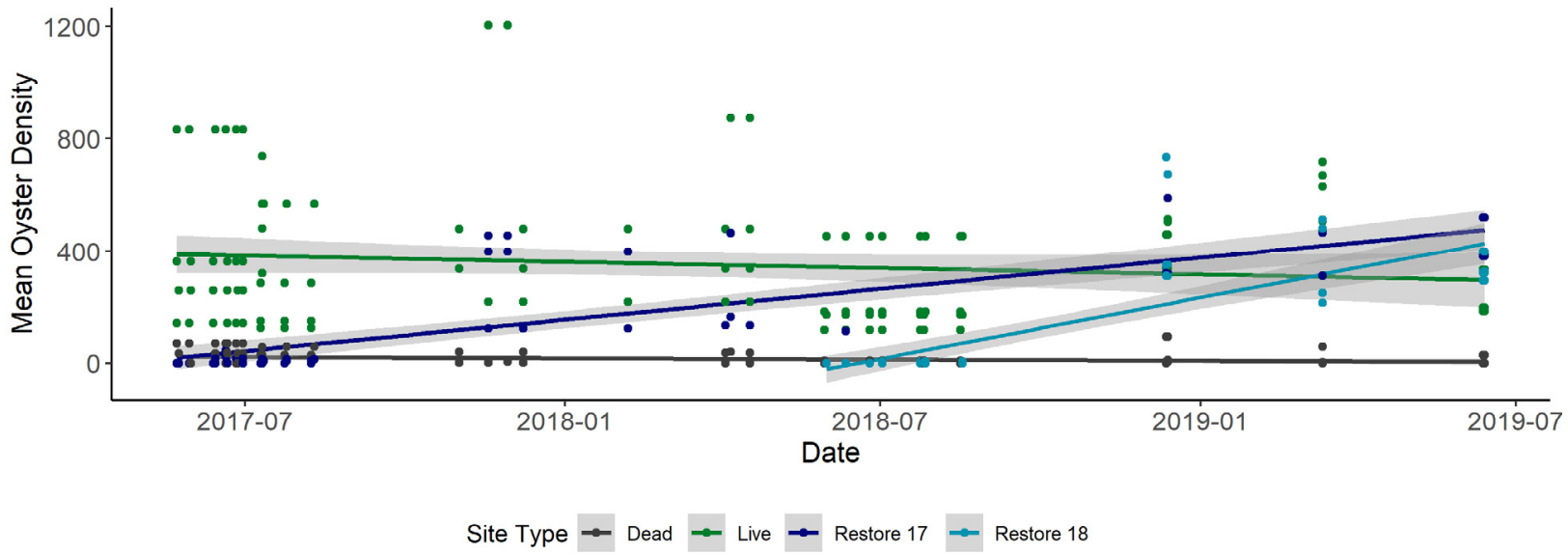

Figure 2. Linear models and raw data (with 95\% CI in grey) of oyster metrics for live, dead, reefs restored in 2017 and reefs restored in 2018: (A) mean reef thickness and (B) oyster density over time.

Table 3. Number of individuals captured across all sampling events and reef types. Gobiosoma spp. is composed of G. bosc and G. robustum under $20 \mathrm{~mm}$ standard length. Note three sites were restored in 2017 and an additional four sites were restored in 2018, all seven of these reefs are pooled under Reef Type Restored.

\begin{tabular}{cccccc}
\hline Species & Common Name & Live $(n=4)$ & $\begin{array}{c}\text { Reef Type } \\
\text { Restored }(n=7)\end{array}$ & Dead $(n=4)$ & $\begin{array}{c}\text { Species } \\
\text { Total }\end{array}$ \\
\hline $\begin{array}{c}\text { Bathygobius } \\
\text { soporator } \\
\begin{array}{c}\text { Chasmodes } \\
\text { saburrae }\end{array}\end{array}$ & Frillfin Goby & 5 & 1 & 13 & 19 \\
$\begin{array}{c}\text { Ctenogobius } \\
\text { boleosoma } \\
\text { Gobiosoma } \\
\begin{array}{c}\text { bosc } \\
\text { Gobiosoma } \\
\text { robustum }\end{array}\end{array}$ & Florida Blenny & 2 & 2 & 8 & 12 \\
$\begin{array}{c}\text { Gobiosoma } \\
\text { spp. }\end{array}$ & Naked Goby & 162 & 36 & 12 & 210 \\
$\begin{array}{c}\text { Microgobius } \\
\text { gulosus }\end{array}$ & Code Goby & 125 & 20 & 15 & 120 \\
$\begin{array}{c}\text { Microgobius } \\
\text { thalassinus } \\
\text { Opsanus tau }\end{array}$ & Green Goby & 180 & 17 & 41 & 183 \\
\hline Oyster Toadfish & Total: & 10 & 64 & 77 & 321 \\
\hline
\end{tabular}




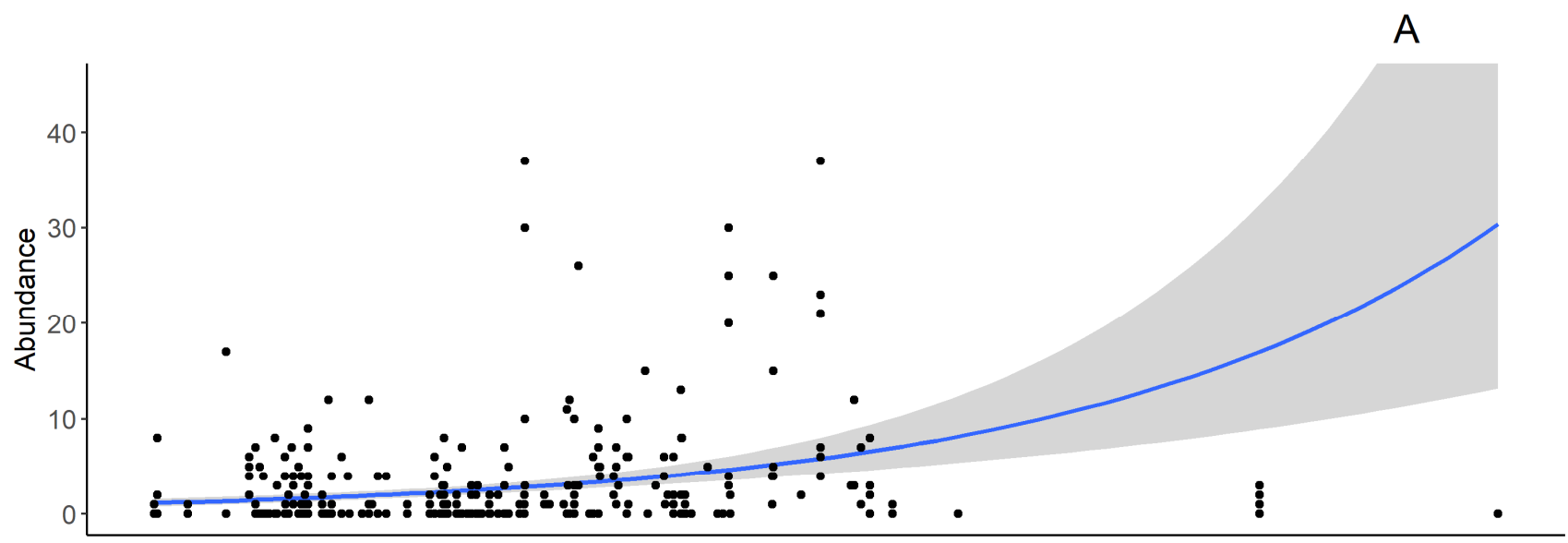

B

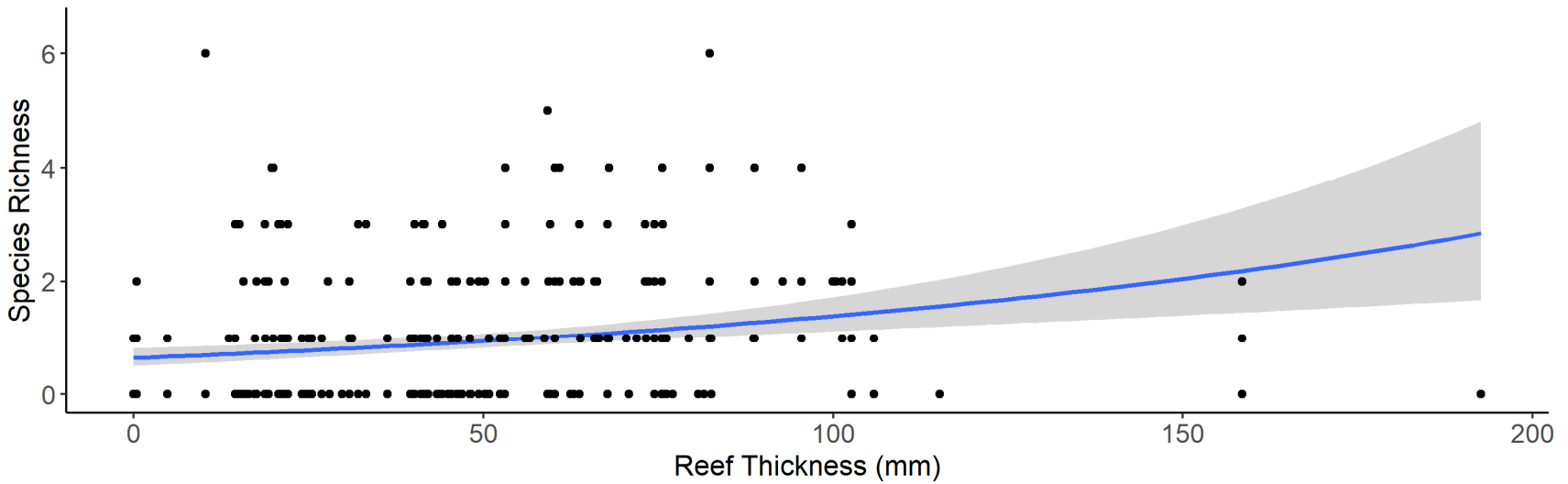

Figure 3. Linear models with negative binomial distributions (with $95 \% \mathrm{CI}$ in grey) between reef thickness and (A) reef resident fish abundance (slope $=0.016, p=0.0026$ ) and $(\mathbf{B})$ species richness (slope $=0.0036, p=0.023$ ). Black dots represent individual sampling events.

Catch per unit effort (CPUE) was greater with lift nets $(n=5.26 /$ lift net sampling event) than seines ( $n=1.47$ / seine sampling event). Generally, reef residents were found in greater abundance in lift nets than seines, with the exception of the Clown Goby, which was found almost entirely in seine catches. When examining the reef resident fish community, more fishes were captured at live reefs than at dead and restored reefs. Cluster analyses and PERMANOVA revealed no distinctions in species assemblage among treatment types, however, it did indicate slight differences in species assemblages by season (Figure 4). The wet and dry seasonality accounted for $13 \%$ of the variation in species assemblages. As preliminary results indicated species abundance and richness data were non-normal, subsequent GLMs were run using a negative binomial distribution with Nagelkerkes pseudo ${ }^{2}$ values reported.

Oyster metrics better predicted reef resident abundance than water quality metrics alone or combined (Table 4). The combination of live oyster density and reef thickness was the best fitting model for predicting annual reef resident abundance ( $\triangle \mathrm{AIC}=0 ; p=0.014$ ). Reef resident abundance, when only including samples collected during the wet season, was best predicted by oyster reef metrics $(\triangle \mathrm{AIC}=0 ; p=0.06)$ and quadratic temperature $(\triangle \mathrm{AIC}=2 ; p=0.002$; Table 4$)$. These models were considerably better fitting than the null models (annual null model $\triangle \mathrm{AIC}=16.5$; wet season null model $\triangle \mathrm{AIC}=7.1$ ). Much of the variance in the data was explained by the best fitting oyster metric models annually $\left(r^{2}=0.43\right)$ and for the wet season $\left(r^{2}=0.31\right)$. Reef thickness alone was the next best fitting models for the annual $\left(\triangle \mathrm{AIC}=11.1 ; p=0.003 ; \mathrm{r}^{2}=0.17\right)$ and wet season reef resident abundances $\left(\triangle \mathrm{AIC}=2.1 ; p=0.02 ; \mathrm{r}^{2}=0.20\right.$; Table 4$)$. 


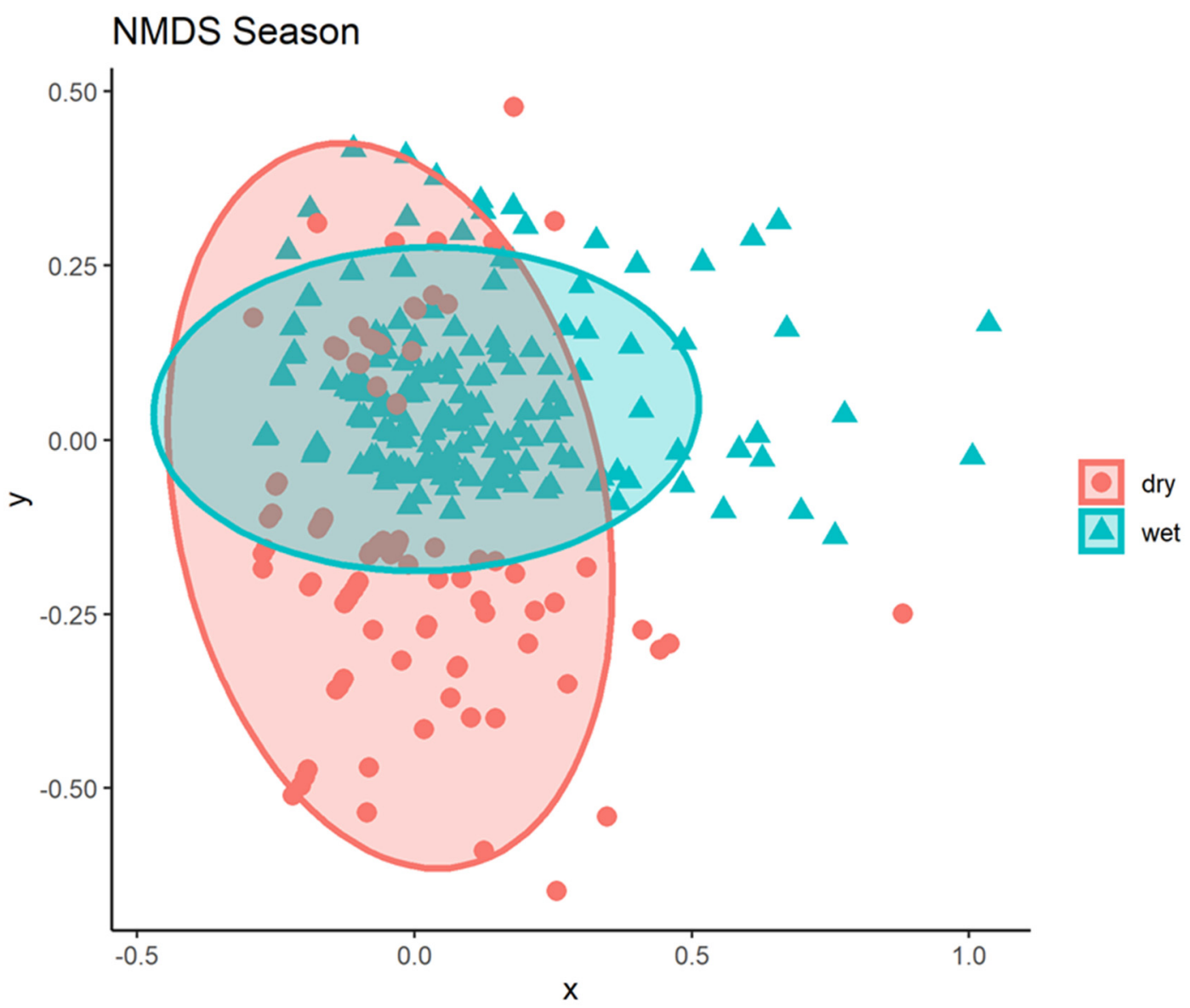

Figure 4. Non-metric multidimensional scaling of species assemblage in wet and dry seasons. Blue triangles represent species assemblages during the wet season and red dots represent species assemblages during the dry season.

Table 4. Oyster and water quality metrics predicting reef resident fish abundance models with negative binomial distribution. All data available are included in the annual models. Only samples collected during the wet season are included in the wet season (May through October) models. Bolded values have $\triangle \mathrm{AIC} \leq 2.0$ (i.e., represent winning models).

\begin{tabular}{ccccccc}
\hline & \multicolumn{3}{c}{ Annual } & \multicolumn{3}{c}{ Wet Season } \\
\hline Abundance Models & $\mathbf{\Delta A I C}$ & $\mathbf{d f}$ & $\boldsymbol{p}$ Value & $\boldsymbol{\Delta A I C}$ & $\mathbf{d f}$ & $p$ Value \\
\hline Reef Thickness & 11.1 & 3 & $0.003^{*}$ & 2.1 & 3 & $0.02^{*}$ \\
Oyster Density & 17.0 & 3 & $2 \times 10^{-16 *}$ & 9.4 & 3 & $2 \times 10^{-16 *}$ \\
Oyster Metrics (reef & $\mathbf{0 . 0}$ & $\mathbf{4}$ & $\mathbf{0 . 0 1 4} *$ & $\mathbf{0 . 0}$ & $\mathbf{4}$ & $\mathbf{0 . 0 6}$ \\
thick + oyster density) & 13.0 & 3 & $1 \times 10^{-8 *}$ & 6.8 & 3 & $3 \times 10^{-5 *}$ \\
Dissolved oxygen & 17.0 & 3 & 0.34 & 8.8 & 3 & 0.12 \\
Temperature & 11.9 & 4 & $0.01 *$ & $\mathbf{2 . 0}$ & $\mathbf{4}$ & $\mathbf{0 . 0 0 2}$ \\
Quadratic Temperature & 18.6 & 3 & 0.04 & 9.3 & 3 & 0.49 \\
Salinity & 17.4 & 4 & 0.13 & 11.7 & 4 & 0.96 \\
Quadratic Salinity & 15.2 & 3 & $8 \times 10^{-7 *}$ & 5.4 & 3 & $6 \times 10^{-6} *$ \\
Secchi & 12.3 & 6 & 0.52 & 4.2 & 6 & $0.01 *$ \\
Water Quality Metrics & 16.5 & 2 & $2 \times 10^{-16 *}$ & 7.1 & 2 & 0.06 \\
Null & & & & &
\end{tabular}

* indicate models with $p$ values less than 0.05 .

Multiple models predicting annual richness, including the null model, were tied for best fit $(\triangle \mathrm{AICs} \leq 2)$ and outperformed the combined water quality metrics model $(\triangle \mathrm{AIC}=6.1$; Table 5$)$. The combined annual oyster metrics model explained the most variation in the data compared to other models with a $p$ value $=0.09\left(\mathrm{r}^{2}=0.12\right)$. During the wet season, six models tied for best fit, including the null model (all $\triangle \mathrm{AICs} \leq 2$ ). Combined 
oyster metrics explained the most variation $\left(\mathrm{r}^{2}=0.17\right)$ in the data and tied for best fitting model with five other models $(\triangle \mathrm{AIC}=0.6$; Table 5).

Table 5. Oyster and water quality metrics predicting reef resident fish species richness models with negative binomial distribution.

\begin{tabular}{|c|c|c|c|c|c|c|}
\hline \multirow[b]{2}{*}{ Richness Models } & \multicolumn{3}{|c|}{ Annual } & \multicolumn{3}{|c|}{ Wet Season } \\
\hline & $\Delta \mathrm{AIC}$ & df & $p$ Value & $\Delta \mathrm{AIC}$ & df & $p$ Value \\
\hline Reef Thickness & 1.2 & 3 & $0.02 *$ & 0.0 & 3 & 0.29 \\
\hline Oyster Density & 2.1 & 3 & $4 \times 10^{-8 *}$ & 2.5 & 3 & $9 \times 10^{-6 *}$ \\
\hline $\begin{array}{c}\text { Oyster Metrics (reef } \\
\text { thick + oyster density) }\end{array}$ & 1.1 & 4 & 0.09 & 0.6 & 4 & 0.48 \\
\hline Dissolved oxygen & 1.6 & 3 & $0.01 *$ & 1.0 & 3 & $0.01 *$ \\
\hline Temperature & 1.9 & 3 & $0.04 *$ & 1.3 & 3 & 0.14 \\
\hline Quadratic Temperature & 2.3 & 4 & 0.32 & 2.4 & 4 & 0.29 \\
\hline Salinity & 1.6 & 3 & 0.13 & 2.0 & 3 & 0.78 \\
\hline Quadratic Salinity & 3.6 & 4 & 0.63 & 4.3 & 4 & 0.89 \\
\hline Secchi & 2.2 & 3 & 0.82 & 2.5 & 3 & 0.25 \\
\hline $\begin{array}{l}\text { All Water Quality } \\
\text { Metrics Combined }\end{array}$ & 6.1 & 6 & 0.837 & 7.4 & 6 & 0.67 \\
\hline Null & 0.0 & 2 & $3 \times 10^{-15 *}$ & 0.3 & 2 & $1 \times 10^{-11 *}$ \\
\hline
\end{tabular}

All data available is included in the annual models. Only samples collected during the wet season are included in the wet season (May-October) models. Bolded values have $\triangle \mathrm{AIC} \leq 2.0$ (i.e., are winning models). Bolded values have $\triangle \mathrm{AIC} 2.0$ (i.e., represent winning models) * represent models with $p$ values less than 0.05 .

\section{Discussion}

This study highlighted the strong relationship between reef resident fishes and oyster reef metrics (i.e., oyster density and reef thickness). Directly following restoration, reef metrics more closely resembled dead reefs. Over the two years of the study, restored reefs began to more closely resemble live reefs with respect to oyster density and oyster reef thickness (Figure 2). When assessing the abundance of the reef resident fish guild, more resident fishes were captured at live reefs than dead and restored reefs (Table 3). The temporal shift in the oyster reefs following restoration (essentially transitioning from a dead reef to a live reef), resulted in low correlations, and reef type being a poor predictor of fish community metrics. However, using oyster density and reef thickness as predictors of reef resident fish metrics gave insight into the response of the resident fish guild to habitat restoration. Reef resident abundance and species richness positively responded to an increase in oyster thickness and count (Figure 3). These results align with Tolley and Volety (2005) suggesting it is not necessarily the number of live oysters alone but the increasing habitat complexity over time that supports and attracts reef resident type fishes (gobies and blennies native to that region). These results suggest projects that create oyster settlement habitat and categorize changes in the faunal community using reef type alone, may miss important gradients of change at higher trophic levels and fail to provide evidence of restoration success throughout the food web.

Using oyster reef thickness and oyster density as a proxy for restoration success (as opposed to using reef type in isolation) in generalized linear models is warranted. Generalized linear models predicting reef resident abundances regardless of season identified the oyster reef model combining reef thickness and oyster density as the best fitting model $(\triangle \mathrm{AIC}=0$; Table 4$)$. This model also explained a considerable amount of variation in the resident reef fish data annually $\left(r^{2}=0.43\right)$ and during the wet season $\left(r^{2}=0.31\right)$. The quadratic temperature model tied with oyster reef metrics during the wet season. This may be indicative of reef resident fishes inhabiting waters closer to their thermal maximum during the wet season which encompasses the warmer summer months. However, reef metrics were still playing a role in reef fish community abundance. Oyster reef thickness was the next best fitting model in both cases and explained more variation than oyster density. Estimates of oyster density indicate annual recruitment pulses occurred at all reef types but reef thickness increased linearly across restored reefs. This implies that for these species, reef complexity may be a stronger driver of total resident fish abundances than 
oyster counts alone. Furthermore, proximity to source populations on live reefs may be a strong driver of which restored reefs receive settlers via larval dispersal.

Predictors of species richness were more complicated and include oyster metrics and water quality variables at annual and seasonal temporal scales. This trend is potentially explained by the relatively low number of reef resident species in this study $(n=8)$, most of which have similar ecological niches (Table 1). Due to this, common diversity metrics such as richness may not be sufficiently fine scale to determine large shifts in habitat use. For instance, the Frillfin Goby and Florida Blenny were found in markedly higher abundances at the base of dead reefs compared to other reef types. These species are known to lay eggs on clean, disarticulated shells; however, these species only accounted for $3 \%$ of total individuals captured and most likely would not impact greatly the relationship between richness and oyster reef metrics $[35,87,88]$.

The community assemblage of reef resident fishes was also similar among reef types, with seven of eight species occurring at all reef types; these species, however, varied greatly in their abundances across reef types (Table 3). These similarities and differences can potentially be attributed to life history strategies of the reef resident species. Most species in this study have similar recruitment periods (i.e., the wet season (May-October) in Florida $[66,67])$. When looking at individual species, certain species that feed on or brood nests directly on oyster shells, such as the Oyster Toadfish and Naked Gobies, mirrored the recruitment pulses in oyster abundance [89-91]. Although sampling efforts were greater in the wet season, when catches were standardized by catch per unit effort, CPUE did increase during the wet season and is most likely due to these recruitment pulses. The preferred reef type of reef residents may change based on season with some species preferring cleaned, disarticulated shell for egg laying and brooding [64,88]. Sampling reef residents over multiple wet seasons would more unequivocally elucidate how newly and previously restored reefs are supporting lower trophic level fishes. In order to provide a more complete understanding of how habitat restoration broadly, and oyster reef restoration in particular, benefits coastal food webs will require a concerted effort in future studies to sample and monitor restored reefs for longer than the two years following restoration that was possible in this study.

Quantifying the benefits of oyster reef restoration to more mobile higher trophic level sportfish is inherently complicated. However, smaller resident fishes with lower relative vagility are less likely to disperse among reefs or estuaries and thus may act as a higher trophic level indicator of restoration success at the local reef scale. Future studies exploring dispersal, spatial configuration of local reefs, and how proximity to live or more mature restored oyster reefs impacts the capacity of reefs to support new recruits of reef residents could provide strategic insight regarding the identification of candidate reefs to restored in the future. By identifying reefs with the greatest demographic connectivity to other reefs, restoration activities could be designed to maximize higher rates of settlement and post-settlement recruitment. In this manner, the network of restored reefs could function as a metapopulation [92,93], thus increasing the persistence and regional carrying capacity of lower trophic level species that in turn can support greater abundances of higher trophic level species within the reef network.

Coastal restoration efforts have been ongoing in many parts of the world, but these projects have experienced varying levels of success [94-97]. Specifically, the restoration of foundation species, large or numerically dominant species such as mangroves, corals, and seagrasses that create habitat or provide food for other species, is increasing, with generally positive results for the related ecosystem and ecosystem services being produced $[6,31,98,99]$. While many strategies to assess the efficacy of restoring foundation species exist, these often struggle to capture the indirect benefits of restoration of the habitat conferred to higher trophic level species reliant on their presence for prey and/or habitat. To evaluate the success of oyster reef restoration, multiple oyster metrics including density, rugosity, and oyster size class structure (following restoration) exist. However other potential metrics of restoration success such as nutrient cycling or support of other 
higher trophic level species such as invertebrates, fishes, and birds are quantified less frequently $[58,100,101]$. These factors, in combination with the logistical constraints related to post-restoration monitoring, result in few quantitative estimates of the benefit of habitat restoration for higher trophic level species such as fishes. Compared to more transient fishes, reef resident fishes greatly rely on oyster reefs to provide habitat for nesting and refugia, in addition to providing prey [48]. Furthermore, small resident fish species are often some of the first to inhabit an area that has been restored; in this study, reef resident fish were collected at six of the seven restored sites as early as one-week post-restoration $(n=21)$. Prior to restoration, only one fish was collected at these sites in pre-restoration sampling. Therefore, these species could act as relatively rapid indicators of restoration success for mid and lower trophic level fishes [35].

\section{Conclusions}

Oyster reef restoration has been used to mitigate impacts from direct harvest, overfishing, boat wakes, and degraded water quality that together have decreased oyster density by nearly $85 \%[36,37,39,40]$. This study demonstrated how oyster reef restoration creates essential fish habitat for resident fish communities in a relatively short period of time ( 12-24 months). The abundances of these species of fish are positively and closely related to oyster reef thickness and abundance (Figure 3; Table 4). Therefore, the abundance of reef resident fishes appears to be a practical indicator of restoration success as these species are an important link to higher trophic level fishes [61,63,91]. Adjusting locations of reefs and closely monitoring settlement/recruitment can provide a novel means of gauging the success of shellfish habitat restoration at higher trophic levels. Using the presence of oyster reef resident species, in addition to setting target levels of abundance observed at live oyster reefs, may be a useful metric for monitoring the function of restored reef habitat at higher trophic levels and provide insight beyond the level of the oyster reef itself. Furthermore, future studies are necessary to determine actual distances smaller demersal fishes disperse during larval stages to help quantify how close restored reefs must be to receive settlers from source populations and how settlement is influenced by patch reef size, shape, configuration, and hydrology. In addition, sizes and sexes of fishes should be assessed in future studies to further elucidate specific behavioral trends such as individuals that are present and breeding versus non-breeding individuals. While results here reaffirm the significance of the interactions between reef-associated species and structural complexity of the reef, they moreover suggest that additional time and monitoring are required to accurately assess if and when the reef resident fish assemblage at restored reefs resembles the fish assemblage at live reefs. If oyster reefs within Mosquito Lagoon continue to suffer degradation from recreational boat wakes [37,79], reductions in resident reef fish abundance could be indicative of a reduction in oyster habitat quality, with implications for other components of the food web. Future studies utilizing methods such as structural equation models to assess higher trophic level species such as sportfish and wading birds, with special foci on their diets and foraging behavior, should be considered to better understand oyster reef restoration impacts on the broader food web [102-110]. Incorporating biotic metrics describing lower trophic level fishes, here a guild of reef resident fishes, can elucidate unseen factors that may result in differences in reef restoration success. In this way, these species can act as indicators of restoration success, and provide insight that can help guide future restoration efforts.

Author Contributions: Conceptualization, D.M.L. and K.E.D.; methodology, D.M.L. and G.S.C.; formal analysis, D.M.L.; investigation, D.M.L. and K.E.D.; resources, G.S.C. and L.J.W.; data curation, D.M.L., G.S.C. and L.J.W.; writing—original draft preparation, D.M.L.; writing—review and editing, K.E.D., G.S.C. and L.J.W.; visualization, D.M.L. and K.E.D.; supervision, G.S.C.; project administration, D.M.L.; funding acquisition, G.S.C. and L.J.W. All authors have read and agreed to the published version of the manuscript.

Funding: This work was funded by the NSF (Award \# BCS-1617374) for providing student stipends and support for sample collections and processing. 
Institutional Review Board Statement: The study was conducted according to the guidelines and approved by the Institutional Review Board University of Central Florida Animal Care and Use Committee Protocol (IACUC Permit \# 16-15W and 19-13W).

Informed Consent Statement: Not applicable.

Data Availability Statement: Data will be made available via the UCF data repository, STARS (https: / / stars.library.ucf.edu/, Accessed: 18 November 2021), within 2 years of publication.

Acknowledgments: We thank the UCF Marine Ecology and Conservation Lab and UCF Coastal and Estuarine Ecology Lab for their assistance and support through sample collection and processing. Article processing charges were provided in part by the UCF College of Graduate Studies Open Access Publishing Fund.

Conflicts of Interest: The authors declare no conflict of interest. The funders had no role in the design of the study; in the collection, analyses, or interpretation of data; in the writing of the manuscript, or in the decision to publish the results.

\section{Appendix A}

Table A1. Individual reef metrics for live, dead, and restored reefs 12 months following restoration (values for reefs restored in 2018 are from the following year compared to other reefs). Elevation measurements begin on reef flat.

\begin{tabular}{cccc}
\hline Reef & Mean Slope $\pm \mathbf{S E}$ & Area $\mathbf{( m}^{\mathbf{2}} \mathbf{~}$ & Mean Elevation $(\mathbf{m}) \pm \mathbf{S E}$ \\
\hline Live 1 & $0.83 \pm 0.18$ & 72.9 & $0.04 \pm 0.01$ \\
Live 2 & $0.44 \pm 0.08$ & 1249 & $0.07 \pm 0.01$ \\
Live 3 & $0.723 \pm 0.09$ & 4387 & $0.11 \pm 0.01$ \\
Live 4 & $0.333 \pm 0.08$ & 460 & $0.04 \pm 0.008$ \\
Dead 1 & $12.79 \pm 0.87$ & 142.2 & $0.45 \pm 0.02$ \\
Dead 2 & $18.93 \pm 1.60$ & 586 & $0.49 \pm 0.13$ \\
Dead 3 & $9.95 \pm 0.63$ & 26.3 & $0.16 \pm 0.01$ \\
Dead 4 & $8.91 \pm 0.79$ & 792 & $0.44 \pm 0.001$ \\
Restore 1 & $0.73 \pm 0.34$ & 109 & $0.04 \pm 0.02$ \\
Restore 2 & $1.30 \pm 0.30$ & 77.7 & $0.07 \pm 0.01$ \\
Restore 4 & $0.41 \pm 0.08$ & 30.6 & $0.03 \pm 0.01$ \\
Restore 5 & $2.54 \pm 0.67$ & 43.8 & $0.11 \pm 0.02$ \\
Restore 6 & $0.73 \pm 0.05$ & 91.2 & $0.05 \pm 0.004$ \\
Restore 7 & $0.69 \pm 0.08$ & 81.6 & $0.04 \pm 0.004$ \\
Restore 8 & $1.27 \pm 0.18$ & 70.9 & $0.07 \pm 0.01$ \\
\hline
\end{tabular}

Table A2. Table 1 citation list. Author citation corresponds with literature cited [88-90,103-110].

\begin{tabular}{|c|c|c|c|c|}
\hline Species & Salinity & Temperature & DO min & Spawning Period \\
\hline Bathygobius soporator & (Darcy 1980) & (Darcy 1980) & (Rummer et al. 2009) & (Darcy 1980) \\
\hline Chasmodes saburrae & (Williams 1983) & (Peters 1981) & NA & (Peters 1981) \\
\hline Ctenogobius boleosoma & (Fritzsche 1978) & (Darcy 1980) & NA & (Darcy 1980) \\
\hline Gobiosoma bosc & (Fritzsche 1978) & (Darcy 1980) & (Saksena and Joseph 1972) & (Darcy 1980) \\
\hline Gobiosoma robustum & (Darcy 1980) & (Darcy 1980) & NA & (Darcy 1980) \\
\hline Microgobius gulosus & (Darcy 1980) & (Darcy 1980) & NA & (Provancha and Hall 1991) \\
\hline Microgobius thalassinus & (Schwartz 1971) & (Schwartz 1971) & NA & (Fritzsche 1978) \\
\hline Opsanus tau & (Monaco and Nelson 1990) & (Mensinger and Tubbs 2006) & (Breitburg 2002) & (Gray and Winn 2010) \\
\hline
\end{tabular}

\section{References}

1. Thrush, S.F.; Dayton, P.K. What Can Ecology Contribute to Ecosystem-Based Management? Annu. Rev. Mar. Sci. 2010,2 , $419-441$. [CrossRef] [PubMed]

2. Kelly, J.R.; Harwell, M.A. Indicators of Ecosystem Recovery. Environ. Manag. 1990, 14, 527-545. [CrossRef]

3. Barbier, E.B.; Hacker, S.D.; Kennedy, C.; Koch, E.W.; Stier, A.C.; Silliman, B.R. The Value of Estuarine and Coastal Ecosystem Services. Ecol. Monogr. 2011, 81, 169-193. [CrossRef] 
4. Cook, G.S.; Fletcher, P.J.; Kelble, C.R. Towards Marine Ecosystem Based Management in South Florida: Investigating the Connections among Ecosystem Pressures, States, and Services in a Complex Coastal System. Ecol. Indic. 2014, 44, 26-39. [CrossRef]

5. Anderson, D.M.; Glibert, P.M.; Burkholder, J.M. Harmful Algal Blooms and Eutrophication Nutrient Sources, Composition, and Consequences. Estuaries 2002, 25, 704-726. [CrossRef]

6. Sorte, C.J.B.; Davidson, V.E.; Franklin, M.C.; Benes, K.M.; Doellman, M.M.; Etter, R.J.; Hannigan, R.E.; Lubchenco, J.; Menge, B.A. Long-Term Declines in an Intertidal Foundation Species Parallel Shifts in Community Composition. Glob. Chang. Biol. 2017, 23, 341-352. [CrossRef] [PubMed]

7. Salewski, E.A.; Proffitt, C.E. Separate and Combined Effects of Estuarine Stress Gradients and Disturbance on Oyster Population Development on Restored Reefs. Estuaries Coasts 2016, 39, 510-528. [CrossRef]

8. Gaylord, B.; Hill, T.M.; Sanford, E.; Lenz, E.A.; Jacobs, L.A.; Sato, K.N.; Russell, A.D.; Hettinger, A. Functional Impacts of Ocean Acidification in an Ecologically Critical Foundation Species. J. Exp. Biol. 2011, 214, 2586-2594. [CrossRef]

9. Angelini, C.; Altieri, A.H.; Silliman, B.R.; Bertness, M.D. Interactions among Foundation Species and Their Consequences for Community Organization, Biodiversity, and Conservation. BioScience 2011, 61, 782-789. [CrossRef]

10. Jackson, J.B.C. What Was Natural in the Coastal Oceans? Proc. Natl. Acad. Sci. USA 2001, 98, 5411-5418. [CrossRef]

11. Stocker, T.F.; Qin, D.; Plattner, G.K.; Tignor, M.; Allen, S.K.; Boschung, J.; Nauels, A.; Xia, Y.; Bex, Y.; Midgley, P.M. IPCC: Climate Change 2013: The Physical Science Basis. Contribution of Working Group I to the Fifth Assessment Report of the Intergovernmental Panel on Climate Change; Cambridge University Press: Cambridge, UK, 2013.

12. Saunders, M.A.; Lea, A.S. Large Contribution of Sea Surface Warming to Recent Increase in Atlantic Hurricane Activity. Nature 2008, 451, 557-560. [CrossRef]

13. Zhang, K. Analysis of Non-Linear Inundation from Sea-Level Rise Using LIDAR Data: A Case Study for South Florida. Clim. Chang. 2011, 106, 537-565. [CrossRef]

14. Kaplan, A.; Cane, M.A.; Kushnir, Y.; Clement, A.C.; Blumenthal, M.B.; Rajagopalan, B. Analyses of Global Sea Surface Temperature 1856-1991. J. Geophys. Res. Oceans 1998, 103, 18567-18589. [CrossRef]

15. Levin, S. Towards a Science of Ecological Management. Conserv. Ecol. 1999, 2017, 1722-1725. [CrossRef]

16. Ham, K.D.; Pearsons, T.N. A Practical Approach for Containing Ecological Risks Associated with Fish Stocking Programs. Fisheries 2001, 26, 15-23. [CrossRef]

17. Pearsons, T.N.; Hopley, C.W. A Practical Approach for Assessing Ecological Risks Associated with Fish Stocking Programs. Fisheries 1999, 24, 16-23. [CrossRef]

18. McNaught, A.S.; Schindler, D.W.; Parker, B.R.; Paul, A.J.; Anderson, R.S.; Donald, D.B.; Agbeti, M. Restoration of the Food Web of an Alpine Lake Following Fish Stocking. Limnol. Oceanogr. 1999, 44, 127-136. [CrossRef]

19. Tallis, H.; Levin, P.S.; Ruckelshaus, M.; Lester, S.E.; Mcleod, K.L.; Fluharty, D.L.; Halpern, B.S. The Many Faces of Ecosystem-Based Management: Making the Process Work Today in Real Places. Mar. Policy 2010, 34, 340-348. [CrossRef]

20. Hilborn, R. Future Directions in Ecosystem Based Fisheries Management: A Personal Perspective. Fish. Res. 2011, 108, 235-239. [CrossRef]

21. Ruckelshaus, M.; Klinger, T.; Knowlton, N.; Douglas, P.; Master, D.E. Marine Ecosystem-Based Management in Practice: Scientific and Governance Challenges. BioScience 2008, 58, 53-63. [CrossRef]

22. Long, R.D.; Charles, A.; Stephenson, R.L. Key Principles of Marine Ecosystem-Based Management. Mar. Policy 2015, 57, 53-60. [CrossRef]

23. Walker, R.; Solecki, W. South Florida: The Reality of Change and the Prospects for Sustainability. Ecol. Econ. 2001, 37, 333-337. [CrossRef]

24. Harding, J.M.; Mann, R. Oyster Reefs as Fish Habitat: Opportunistic Use of Restored Reefs by Transient Fishes. J. Shellfish Res. 2001, 20, 951-959.

25. Rosenberg, A.; Bigford, T.E.; Leathery, S.; Hill, R.L.; Bickers, K. Ecosystem Approaches to Fishery Management through Essential Fish Habitat. Bull. Mar. Sci. 2000, 66, 535-542.

26. Able, K.W. Measures of Juvenile Fish Habitat Quality: Examples from a National Estuarine Research Reserve. In Proceedings of the Fish Habitat: Essential Fish Habitat and Rehabilitation; Benaka, L.R., Ed.; American Fisheries Society: Bethesda, MD, USA, 1999; pp. 134-147.

27. Minello, T.J. Nekton Densities in Shallow Estuarine Habitats of Texas and Louisiana and the Identification of Essential Fish Habitat. In Proceedings of the Fish Habitat: Essential Fish Habitat and Rehabilitation; Benaka, L.R., Ed.; American Fisheries Society: Bethesda, MD, USA, 1999; pp. 43-75.

28. Byers, J.E.; Cuddington, K.; Jones, C.G.; Talley, T.S.; Hastings, A.; Lambrinos, J.G.; Crooks, J.A.; Wilson, W.G. Using Ecosystem Engineers to Restore Ecological Systems. Trends Ecol. Evol. 2006, 21, 493-500. [CrossRef]

29. Jones, C.G.; Lawron, J.H.; Shachak, M. Positive and Negative Effects of Organisms as Physical Ecosystem Engineers. Ecology 1997, 78, 1946-1957. [CrossRef]

30. Coleman, F.C.; Williams, S.L. Overexploiting Marine Ecosystem Engineers: Potential Consequences for Biodiversity. Trends Ecol. Evol. 2002, 17, 40-44. [CrossRef]

31. Dayton, P.K. Competition, Disturbance, and Community Organization: The Provision and Subsequent Utilization of Space in a Rocky Intertidal Community. Ecol. Monogr. 1971, 41, 351-389. [CrossRef] 
32. Short, F.T.; Wyllie-Echeverria, S. Natural and Human-Induced Disturbance of Seagrasses. Environ. Conserv. 1996, $23,17-27$. [CrossRef]

33. Coen, L.D.; Brumbaugh, R.D.; Bushek, D.; Grizzle, R.; Luckenbach, M.W.; Posey, M.H.; Powers, S.P.; Tolley, S.G. Ecosystem Services Related to Oyster Restoration. Mar. Ecol. Prog. Ser. 2007, 341, 303-307. [CrossRef]

34. Coen, L.D.; Luckenbach, M.W.; Breitburg, D.L. The Role of Oyster Reefs as Essential Fish Habitat: A Review of Current Knowledge and Some New Perspectives. In Proceedings of the Fish Habitat: Essential Fish Habitat and Rehabilitation; American Fisheries Society: Bethesda, MD, USA, 1999.

35. Tolley, S.G.; Volety, A.K. The Role of Oysters in Habitat Use of Oyster Reefs by Resident Fishes and Decapod Crustaceans. J. Shellfish Res. 2005, 24, 1007-1012. [CrossRef]

36. Manis, J.E.; Garvis, S.K.; Jachec, S.M.; Walters, L.J. Wave Attenuation Experiments over Living Shorelines over Time: A Wave Tank Study to Assess Recreational Boating Pressures. J. Bus. Psychol. 2015, 30, 1-11. [CrossRef]

37. Wall, A.L.M.; Walters, L.J.; Grizzle, R.E.; Sacks, P.E. Recreational Boating Activity and Its Impact on the Recruitment and Survival of the Oyster Crassostrea virginica on Intertidal Reefs in Mosquito Lagoon, Florida. J. Shellfish Res. 2005, 24, 965-973. [CrossRef]

38. Peterson, C.H.; Grabowski, J.H.; Powers, S.P. Estimated Enhancement of Fish Production Resulting from Restoring Oyster Reef Habitat: Quantitative Valuation. Mar. Ecol. Prog. Ser. 2003, 264, 249-264. [CrossRef]

39. Newell, R.E. Ecological Changes in Chesapeake Bay: Are They the Result of Overharvesting the American Oyster, Crassostrea virginica. Underst. Estuary Adv. Chesap. Bay Res. 1988, 129, 536-546.

40. Beck, M.W.; Brumbaugh, R.D.; Airoldi, L.; Carranza, A.; Coen, L.D.; Crawford, C.; Defeo, O.; Edgar, G.J.; Hancock, B.; Kay, M.C.; et al. Oyster Reefs at Risk and Recommendations for Conservation, Restoration, and Management. BioScience 2011, 61, 107-116. [CrossRef]

41. Zu Ermgassen, P.S.E.; Spalding, M.D.; Blake, B.; Coen, L.D.; Dumbauld, B.; Geiger, S.; Grabowski, J.H.; Grizzle, R.; Luckenbach, M.; McGraw, K.; et al. Historical Ecology with Real Numbers: Past and Present Extent and Biomass of an Imperilled Estuarine Habitat. Proc. R. Soc. B Biol. Sci. 2012, 279, 3393-3400. [CrossRef]

42. Zu Ermgassen, P.S.E.; Spalding, M.D.; Grizzle, R.E.; Brumbaugh, R.D. Quantifying the Loss of a Marine Ecosystem Service: Filtration by the Eastern Oyster in US Estuaries. Estuaries Coasts 2013, 36, 36-43. [CrossRef]

43. Chanton, J.; Lewis, F.G. Examination of Coupling between Primary and Secondary Production in a River-Dominated Estuary: Apalachicola Bay, Florida, USA. Limnol. Oceanogr. 2002, 47, 683-697. [CrossRef]

44. Pauly, D.; Christensen, V.; Guénette, S.; Pitcher, T.J.; Sumaila, U.R.; Walters, C.J.; Watson, R.; Zeller, D. Towards Sustainability in World Fisheries. Nature 2002, 418, 689-695. [CrossRef]

45. Abeels, H.A.; Loh, A.N.; Volety, A.K. Trophic Transfer and Habitat Use of Oyster Crassostrea virginica Reefs in Southwest Florida, Identified by Stable Isotope Analysis. Mar. Ecol. Prog. Ser. 2012, 462, 125-142. [CrossRef]

46. Ulanowicz, R.E.; Tuttle, J.H. The Trophic Consequences of Oyster Stock Rehabilitation in Chesapeake Bay. Estuaries J. Estuar. Res. Fed. 1992, 15, 298-306. [CrossRef]

47. Baird, D.; Ulanowicz, R.E. The Seasonal Dynamics of the Chesapeake Bay Ecosystem. Ecol. Monogr. 1989, 59, 329-364. [CrossRef]

48. Kennedy, V.S.; Breitburg, D.L.; Christman, M.C.; Luckenbach, M.W.; Paynter, K.; Kramer, J.; Sellner, K.G.; Dew-Baxter, J.; Keller, C.; Mann, R. Lessons Learned from Efforts to Restore Oyster Populations in Maryland and Virginia, 1990 to 2007. J. Shellfish Res. 2011, 30, 719-731. [CrossRef]

49. Southworth, M.; Mann, R. Oyster Reef Broodstock Enhancement in the Great Wicomico River, Virginia. J. Shellfish Res. 1998, 17, 1101-1114.

50. Grabowski, J.H.; Brumbaugh, R.D.; Conrad, R.F.; Keeler, A.G.; Opaluch, J.J.; Peterson, C.H.; Piehler, M.F.; Powers, S.P.; Smyth, A.R. Economic Valuation of Ecosystem Services Provided by Oyster Reefs. BioScience 2012, 62, 900-909. [CrossRef]

51. Coen, L.D.; Luckenbach, M.W. Developing Success Criteria and Goals for Evaluating Oyster Reef Restoration: Ecological Function or Resource Exploitation? Ecol. Eng. 2000, 15, 323-343. [CrossRef]

52. McClenachan, G.; Witt, M.; Walters, L.J. Replacement of Oyster Reefs by Mangroves: Unexpected Climate-Driven Ecosystem Shifts. Glob. Chang. Biol. 2021, 27, 1226-1238. [CrossRef] [PubMed]

53. Zu Ermgassen, P.S.E.; Deangelis, B.M.; Gair, J.R.; MacDonald, T.C.; Meckley, K.; Powers, S.; Riberia, M.; Rozas, L.P.; Grabowski, J.H. Estimating and Applying Fish and Invertebrate Density and Production Enhancement from Seagrass, Salt Marsh Edge, and Oyster Reef Nursery Habitats in the Gulf of Mexico. Estuaries Coasts 2021, 44, 1588-1603. [CrossRef]

54. Barber, A.; Walters, L.J.; Birch, A. Potential for Restoring Biodiversity of Macroflora and Macrofauna on Oyster Reefs in Mosquito Lagoon, Florida. Biol. Sci. 2010, 73, 47-63.

55. Peterson, C.H.; Summerson, H.C.; Thomson, E.; Lenihan, H.S.; Grabowski, J.; Manning, L.; Micheli, F.; Johnson, G. Synthesis of Linkages between Benthic and Fish Communities as a Key to Protecting Essential Fish Habitat. Bull. Mar. Sci. 2000, 66, 759-774.

56. Luckenbach, M.W.; Coen, L.D.; Ross, P.G.; Stephen, J.A. Oyster Reef Habitat Restoration: Relationships between Oyster Abundance and Community Development Based on Two Studies in Virginia and South Carolina. J. Coast. Res. 2005, 21, 64-78.

57. Rutledge, K.M.; Alphin, T.; Posey, M. Fish Utilization of Created vs. Natural Oyster Reefs (Crassostrea virginica). Estuaries Coasts 2018, 41, 2426-2432. [CrossRef]

58. De Santiago, K.; Palmer, T.A.; Dumesnil, M.; Pollack, J.B. Rapid Development of a Restored Oyster Reef Facilitates Habitat Provision for Estuarine Fauna. Restor. Ecol. 2019, 27, 870-880. [CrossRef] 
59. Layman, C.A.; Jud, Z.R.; Arrington, D.A.; Sabin, D. Using Fish Behavior to Assess Habitat Quality of a Restored Oyster Reef. Ecol. Restor. 2014, 32, 140-143. [CrossRef]

60. Yeager, L.A.; Layman, C.A. Energy Flow to Two Abundant Consumers in a Subtropical Oyster Reef Food Web. Aquat. Ecol. 2011, 45, 267-277. [CrossRef]

61. D'Aguillo, M.C.; Harold, A.S.; Darden, T.L. Diet Composition and Feeding Ecology of the Naked Goby Gobiosoma Bosc (Gobiidae) from Four Western Atlantic Estuaries. J. Fish Biol. 2014, 85, 355-373. [CrossRef] [PubMed]

62. Boudreaux, M.L.; Stiner, J.L.; Walters, L.J. Biodiversity of Sessile and Motile Macrofauna on Intertidal Oyster Reefs in Mosquito Lagoon, Florida. J. Shellfish Res. 2006, 25, 1079-1089. [CrossRef]

63. Harding, J.M.; Allen, D.M.; Haffey, E.R.; Hoffman, K.M. Site Fidelity of Oyster Reef Blennies and Gobies in Saltmarsh Tidal Creeks. Estuaries Coasts 2020, 43, 409-423. [CrossRef]

64. Breitburg, D.L. Settlement Patterns and Presettlement Behavior of the Naked Goby, Gobiosoma Bosci, a Temperate Oyster Reef Fish. Mar. Biol. 1991, 109, 213-221. [CrossRef]

65. Sponaugle, S.; Cowen, R.K. Larval Durations and Recruitment Patterns of Two Caribbean Gobies (Gobiidae): Contrasting Early Life Histories in Demersal Spawners. Mar. Biol. 1994, 120, 133-143. [CrossRef]

66. Guentzel, J.L.; Landing, W.M.; Gill, G.A.; Pollman, C.D. Processes Influencing Rainfall Deposition of Mercury in Florida. Environ. Sci. Technol. 2001, 35, 863-873. [CrossRef] [PubMed]

67. Misra, V.; DiNapoli, S.M. Understanding the Wet Season Variations over Florida. Clim. Dyn. 2013, 40, 1361-1372. [CrossRef]

68. Humphries, A.T.; Peyre, M.K.; Decossas, G.A. The Effect of Structural Complexity, Prey Density, and "Predator-Free Space" on Prey Survivorship at Created Oyster Reef Mesocosms. PLoS ONE 2011, 6, e28339. [CrossRef]

69. Grabowski, J.H.; Hughes, A.R.; Kimbro, D.L. Habitat Complexity Influences Cascading Effects of Multiple Predators. Ecology 2008, 89, 3413-3422. [CrossRef] [PubMed]

70. Bakun, A.; Babcock, E.A.; Lluch-Cota, S.E.; Santora, C.; Salvadeo, C.J. Issues of Ecosystem-Based Management of Forage Fisheries in "Open" Non-Stationary Ecosystems: The Example of the Sardine Fishery in the Gulf of California. Rev. Fish Biol. Fish. 2010, 20, 9-29. [CrossRef]

71. Gilmore, R.G.; Donohoe, C.; Cooke, D.; Herrema, D. Fishes of the Indian River Lagoon and Adjacent Waters, Florida; Harbor Branch Foundation: Fort Pierce, FL, USA, 1977; ISBN 0127518509.

72. Troast, B.; Paperno, R.; Cook, G.S. Multidecadal Shifts in Fish Community Diversity across a Dynamic Biogeographic Transition Zone. Divers. Distrib. 2020, 26, 93-107. [CrossRef]

73. Phlips, E.J.; Badylak, S.; Lasi, M.A.; Chamberlain, R.; Green, W.C.; Hall, L.M.; Hart, J.A.; Lockwood, J.C.; Miller, J.D.; Morris, L.J.; et al. From Red Tides to Green and Brown Tides: Bloom Dynamics in a Restricted Subtropical Lagoon under Shifting Climatic Conditions. Estuaries Coasts 2015, 38, 886-904. [CrossRef]

74. Lewis, D.M.; Troast, B.V.; Glomb, J.C.; Cook, G.S. An Ecological Characterization of Fish Assemblages in Mosquito Lagoon, Florida. Southeast. Nat. 2020, 19, 491. [CrossRef]

75. Paperno, R.; Mille, K.J.; Kadison, E. Patterns in Species Composition of Fish and Selected Invertebrate Assemblages in Estuarine Subregions near Ponce de Leon Inlet, Florida. Estuar. Coast. Shelf Sci. 2001, 52, 117-130. [CrossRef]

76. Smith, N.P. Tidal and Nontidal Flushing of Florida's Indian River Lagoon. Estuaries 1993, 16, 739-746. [CrossRef]

77. Walters, L.J.; Sacks, P.E.; Campbell, D.E. Proceedings of Indian River Lagoon Symposium: Boating Impacts and Boat-Wake Resilient Restoration of the Eastern Oyster Crassostrea virginica in Mosquito Lagoon, Florida, USA. Fla. Sci. 2021, 84, 173-199.

78. Stiner, J.L.; Walters, L.J. Effects of Recreational Boating on Oyster Reef Architecture and Species Interactions. Fla. Acad. Sci. 2008, $71,31-44$.

79. Garvis, S.K.; Sacks, P.E.; Walters, L.J. Formation, Movement, and Restoration of Dead Intertidal Oyster Reefs in Canaveral National Seashore and Mosquito Lagoon, Florida. J. Shellfish Res. 2015, 34, 251-258. [CrossRef]

80. Chambers, L.G.; Gaspar, S.A.; Pilato, C.J.; Steinmuller, H.E.; McCarthy, K.J.; Sacks, P.E.; Walters, L.J. How Well Do Restored Intertidal Oyster Reefs Support Key Biogeochemical Properties in a Coastal Lagoon? Estuaries Coasts 2018, 41, 784-799. [CrossRef]

81. Baggett, L.P.; Powers, S.P.; Brumbaugh, R.D.; Coen, L.D.; Deangelis, B.M.; Greene, J.K.; Hancock, B.T.; Morlock, S.M.; Allen, B.L.; Breitburg, D.L.; et al. Guidelines for Evaluating Performance of Oyster Habitat Restoration. Restor. Ecol. 2015, 23, 737-745. [CrossRef]

82. Stevens, P.W.; Blewett, D.A.; Casey, J.P. Short-Term Effects of a Low Dissolved Oxygen Event on Estuarine Fish Assemblages Following the Passage of Hurricane Charley. Estuaries Coasts 2006, 29, 997-1003. [CrossRef]

83. Walters, K.; Coen, L.D. A Comparison of Statistical Approaches to Analyzing Community Convergence between Natural and Constructed Oyster Reefs. J. Exp. Mar. Biol. Ecol. 2006, 330, 81-95. [CrossRef]

84. Fox, J.; Weisberg, S. An R Companion to Applied Regression 2019. Available online: https://www.tandfonline.com/doi/abs/10 .1080/10543406.2012.635980?journalCode=lbps20 (accessed on 18 November 2021).

85. McClanahan, T.R. A Coral Reef Ecosystem-Fisheries Model: Impacts of Fishing Intensity and Catch Selection on Reef Structure and Processes. Ecol. Model. 1995, 80, 1-19. [CrossRef]

86. Sonnier, G.; Shipley, B.; Navas, M.L. Quantifying Relationships between Traits and Explicitly Measured Gradients of Stress and Disturbance in Early Successional Plant Communities. J. Veg. Sci. 2010, 21, 1014-1024. [CrossRef] 
87. Rummer, J.L.; Fangue, N.A.; Jordan, H.L.; Tiffany, B.N.; Blansit, K.J.; Galleher, S.; Kirkpatrick, A.; Kizlauskas, A.A.; Pomory, C.M.; Bennett, W.A. Physiological Tolerance to Hyperthermia and Hypoxia and Effects on Species Richness and Distribution of Rockpool Fishes of Loggerhead Key, Dry Tortugas National Park. J. Exp. Mar. Biol. Ecol. 2009, 371, 155-162. [CrossRef]

88. Peters, K.M. Reproductive Biology and Developmental Osteology of the Florida Blenny, Chasmodes Saburrae (Perciformes: Blenniidae). Northeast Gulf Sci. 1981, 4, 2. [CrossRef]

89. Gray, G.A.; Winn, H.E. Reproductive Ecology and Sound Production of the Toadfish, Opsanus Tau. Ecol. Soc. Am. 2010, 42, 274-282. [CrossRef]

90. Mensinger, A.F.; Tubbs, M.E. Effects of Temperature and Diet on the Growth Rate of Year 0 Oyster Toadfish, Opsanus Tau. Biol. Bull. 2006, 210, 64-71. [CrossRef] [PubMed]

91. Harding, J.M. Selective Feeding Behavior of Larval Naked Gobies Gobiosoma Bosc and Blennies Chasmodes Bosquianus and Hypsoblennius Hentzi: Preferences for Bivalve Veligers. Mar. Ecol. Prog. Ser. 1999, 179, 145-153. [CrossRef]

92. Carson, H.S.; Levin, L.A.; Cook, G.S.; López-Duarte, P.C. Evaluating the Importance of Demographic Connectivity in a Marine Metapopulation. Ecology 2011, 92, 1972-1984. [CrossRef] [PubMed]

93. Cook, G.S.; Parnell, P.E.; Levin, L.A. Population Connectivity Shifts at High Frequency within an Open-Coast Marine Protected Area Network. PLoS ONE 2014, 9, e103654. [CrossRef]

94. Lefcheck, J.S.; Orth, R.J.; Dennison, W.C.; Wilcox, D.J.; Murphy, R.R.; Keisman, J.; Gurbisz, C.; Hannam, M.; Brooke Landry, J.; Moore, K.A.; et al. Long-Term Nutrient Reductions Lead to the Unprecedented Recovery of a Temperate Coastal Region. Proc. Natl. Acad. Sci. USA 2018, 115, 3658-3662. [CrossRef]

95. Ladd, M.C.; Miller, M.W.; Hunt, J.H.; Sharp, W.C.; Burkepile, D.E. Harnessing Ecological Processes to Facilitate Coral Restoration. Front. Ecol. Environ. 2018, 16, 239-247. [CrossRef]

96. van Katwijk, M.M.; Thorhaug, A.; Marbà, N.; Orth, R.J.; Duarte, C.M.; Kendrick, G.A.; Althuizen, I.H.J.; Balestri, E.; Bernard, G.; Cambridge, M.L.; et al. Global Analysis of Seagrass Restoration: The Importance of Large-Scale Planting. J. Appl. Ecol. 2016, 53, 567-578. [CrossRef]

97. Lewis, R.R. Ecological Engineering for Successful Management and Restoration of Mangrove Forests. Ecol. Eng. 2005, 24, 403-418. [CrossRef]

98. Edmunds, P.J.; Riegl, B. Urgent Need for Coral Demography in a World Where Corals Are Disappearing. Mar. Ecol. Prog. Ser. 2020, 635, 233-242. [CrossRef]

99. Waycott, M.; Duarte, C.M.; Carruthers, T.J.B.; Orth, R.J.; Dennison, W.C.; Olyarnik, S.; Calladine, A.; Fourqurean, J.W.; Heck, K.L.; Hughes, A.R.; et al. Accelerating Loss of Seagrasses across the Globe Threatens Coastal Ecosystems. Proc. Natl. Acad. Sci. USA 2009, 106, 12377-12381. [CrossRef]

100. Loch, J.M.H.; Walters, L.J.; Cook, G.S. Recovering Trophic Structure through Habitat Restoration: A Review. Food Webs 2020, 25, e00162. [CrossRef]

101. Shaffer, M.; Donnelly, M.; Walters, L.J. Does Intertidal Oyster Reef Restoration Affect Avian Community Structure and Behavior in a Shallow Estuarine System? A Post-Restoration Analysis. Fla. Field Nat. 2019, 47, 37-59.

102. Lewis, D.M.; Thompson, K.A.; Macdonald, T.C.; Cook, G.S. Understanding Shifts in Estuarine Fish Communities Following Disturbances Using an Ensemble Modeling Framework. Ecol. Indic. 2021, 126, 107623. [CrossRef]

103. Schwartz, F.J. Biology of Microgobius Thalassinus (Pisces: Gobiidae), a Sponge-Inhabiting Goby of Chesapeake Bay, with Range Extensions of Two Goby Associates. Chesap. Sci. 1971, 12, 156-166. [CrossRef]

104. Saksena, V.P.; Joseph, E.B. Dissolved Oxygen Requirements of Newly-Hatched Larvae of the Striped Blenny (Chasmodes bosquianus), the Naked Goby (Gobiosoma bosci), and the Skilletfish (Gobiesox strumosus). Chesap. Sci. 1972, 13, 23-28. [CrossRef]

105. Fritzsche, R.A. Development of Fishes of the Mid-Atlantic Bight: An Atlas of Egg, Larval and Juvenile Stages; U.S. Fish and Wildlife Service: Solomons, MD, USA, 1978.

106. Darcy, G.H. Comparison of Ecological and Life History Information on Gobiid Fishes, with Emphasis on the South-Eastern United; NOAA: Rockville, MD, USA, 1980.

107. Williams, J.T. Taxonomy and Ecology of the Genus Chasmodes (Pisces: Blenniidae) with a Discussion of Its Zoogeography. Bull. Fla. State Mus. Biol. Sci. 1983, 29, 65-101.

108. Monaco, M.E.; Nelson, D.A. A Proposed Estuarine Classification: Analysis of Species Salinity Ranges; NOAA: Rockville, MD, USA, 1990. Available online: https:// repository.library.noaa.gov/view/noaa/5380 (accessed on 18 November 2021).

109. Provancha, M.J.; Hall, C.R. Ecology and Life History of the Clown Goby Inhabiting the Upper Banana River, Cape Canaveral, Florida. Environ. Biol. Fishes 1991, 31, 41-54. [CrossRef]

110. Breitburg, D. Effects of Hypoxia, and the Balance between Hypoxia and Enrichment, on Coastal Fishes and Fisheries. Estuaries 2002, 25, 767-781. [CrossRef] 